\title{
Relationship between chronic sclerosing dacryoadenitis with high level of lgG4 and Castleman disease
}

This article was published in the following Dove Press journal:

Clinical Ophthalmology

23 December 2010

Number of times this article has been viewed

\author{
Toshiyuki Oshitari' \\ Jiro Yotsukura' \\ Kaoru Asahagi' \\ Takayuki Baba' \\ Takashi Kishimoto ${ }^{2}$ \\ Shuichi Yamamoto' \\ 'Department of Ophthalmology \\ and Visual Science, ${ }^{2}$ Department \\ of Molecular Pathology, Chiba \\ University Graduate School \\ of Medicine, Chiba, Japan
}

\begin{abstract}
The purpose of this study is to present a case of chronic sclerosing dacryoadenitis with high level of IgG4 in a patient diagnosed earlier with Castleman disease. A 79-year-old man noticed a swelling of his lower left jaw that was first seen 8 years earlier. He was diagnosed with Castleman disease from the histopathological examination of a biopsy of the submandibular gland. Since then, the size of the gland had not changed, and he had no systemic inflammatory signs or symptoms. He developed diplopia a year earlier, and CT scans showed bilateral swelling of the lacrimal glands. He was referred to our hospital for further examinations. The patient underwent partial dacryoadenectomy. From the histopathological examinations, he was diagnosed with chronic sclerosing dacryoadenitis with high level of the serum IgG4. He underwent oral steroid therapy and the swollen lacrimal glands were significantly improved. The results suggest that there may be pathological links between IgG4-related dacryoadenitis and Castleman disease.
\end{abstract}

Keywords: IgG4, dacryoadenitis, Castleman disease, steroid

\section{Introduction}

The pathogenesis of IgG4-related dacryoadenitis and Mikulicz's disease is different from that of Sjögren syndrome. ${ }^{1}$ However, the precise pathological definition of IgG4-related dacryoadenitis is still debated because there are other diseases with similar clinicopathological features, eg, Castleman disease. ${ }^{2}$ We report a case of chronic sclerosing bilateral dacryoadenitis with high level of the serum IgG4 that had been diagnosed with Castleman disease from the histopathological findings of a submandibular gland biopsy.

\section{Case report}

A 79-year-old man first noticed a swelling of his lower left jaw 8 years earlier. He was diagnosed with Castleman disease by histopathological examinations of a specimen from a swollen submandibular gland 6 years earlier. Since then, the size of the swollen gland had not changed and he had no symptoms or signs of systemic inflammation. He developed diplopia a year ago, and CT scans showed swelling of the lacrimal glands bilaterally, and he was referred to our hospital for further examinations.

Our examination showed that his visual acuities were slightly reduced to $0.8 \mathrm{OD}$, 0.5 OS because of moderate cataracts. The intraocular pressures and fundus findings were within normal limits. His left eye was shifted to downward because of a swollen lacrimal gland. The results of the Schirmer test were within normal limits, but MRI 
findings showed bilateral lacrimal gland swelling (Figure 1). He had no visual field defects but his eye movements were slightly restricted. He had no histories of systemic symptoms such as weight loss, skin legions, HIV infection, or recent vaccinations.

He underwent partial dacryoadenectomy on the right side because it was easier to approach than the left side. Histopathological examination of the lacrimal gland biopsy showed inflammatory cells that resembled the histology of Castleman disease (Figure 2). However, some histopathological findings did not agree with the histology of Castleman disease (Figure 2). His blood tests showed high levels of interleukin-6 (IL-6; $5.1 \mathrm{pg} / \mathrm{mL}$ ), IL-2 receptor (1168 U/mL), and IgG (2790 mg/dL), which are consistent with Castleman disease. However, the serum level of IgG4 was also high (695 mg/dL). Immunohistochemical analysis showed that the specimen was not positive for IgG4 (data not shown). The final diagnosis was that our patient had chronic sclerosing dacryoadenitis with high level of the serum IgG4 in addition to Castleman disease.

He underwent oral steroid therapy (30 mg) and the swollen lacrimal glands and his double vision were significantly improved (Figure 3). His last examination 6 months after the steroid therapy showed that his lacrimal glands were not changed.

\section{Discussion}

Multicentric Castleman disease is a rare but life-threatening disease, and its prognosis is completely different from that of IgG4-related disease. ${ }^{2}$ In some patients with Castleman disease, the serum IgG4 levels is increased, ${ }^{3-5}$ and the histopathological findings, such as plasma cell infiltrations surrounding the follicles, are also similar in these diseases. ${ }^{6,7}$ Thus, there may be pathological links between Castleman disease and IgG4-related diseases.

Castleman disease of the lacrimal glands is extremely rare, but unfortunately the serum IgG4 levels have not been reported in the earlier cases. ${ }^{7-10}$ Because the signs and the symptoms of both diseases may overlap, clinicians should

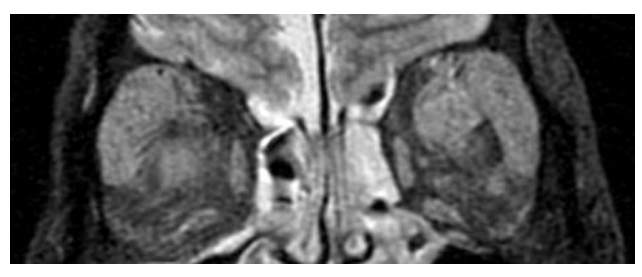

Figure I T2 MRI images of a patient with swollen lacrimal glands. The MRI images were obtained at the first visit to our hospital. The MRI findings indicate extreme swelling of both lacrimal glands.
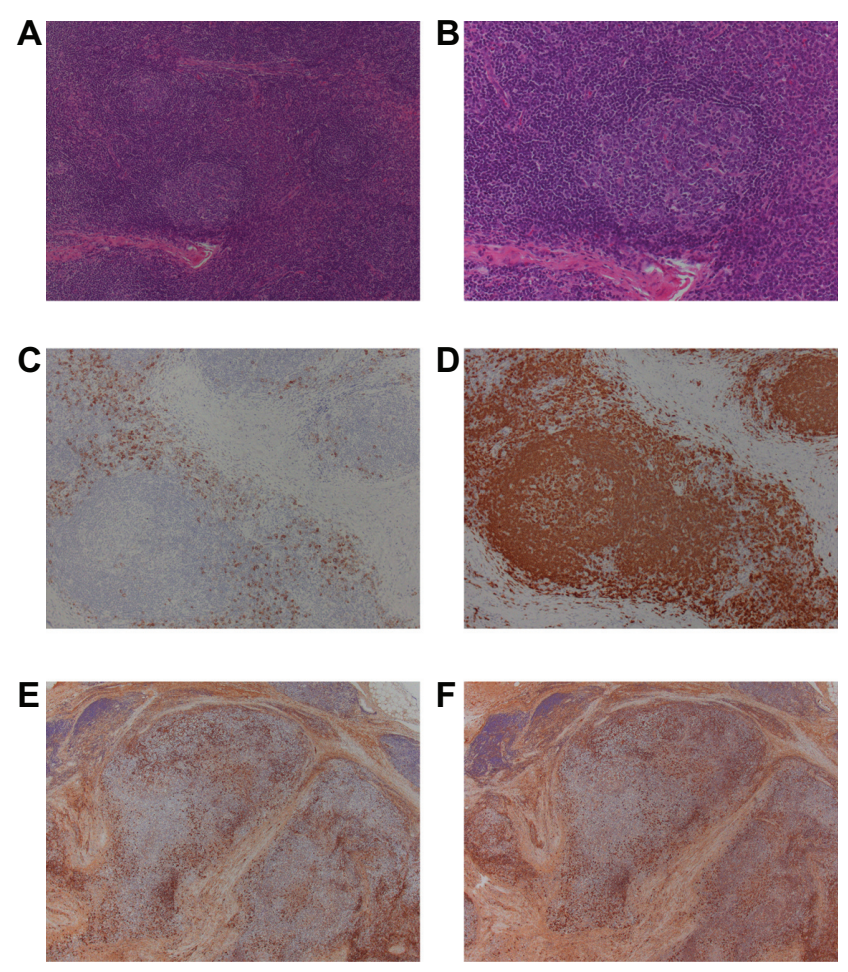

Figure 2 Histopathological findings in a specimen of the right lacrimal gland. H\&E staining at low magnification $(\mathbf{A} \times 100)$ and high magnification $(\mathbf{B} \times 200)$ showing infiltration of plasma cells surrounding the mantle zones and a pattern of concentric deposits with lymphoid cells. These are pathognomic of Castleman disease. The infiltrated cells surrounding the mantle zones were CDI38 (C $\times 100)$, Igkappa $(\mathbf{E} \times 100)$, Iglambda $(\mathbf{F} \times 100)$, and CD79a positive $(\mathbf{D} \times 100)$. However, compared to plasma cell type of Castleman disease, fibrosis in the interstitial tissue was relatively greater. Compared to hyaline-vascular type of Castleman disease, vascularization in the intrafollicular area was relatively poor. The development of mantle zones and the pattern of concentric deposits with infiltrating cells are not of typical of Castleman disease. We finally decided these tissues resemble reactive lesions rather than Castleman disease.

examine the serum IgG4 levels in patients with Castleman disease routinely. ${ }^{2-5}$

In our case, the serum levels of both IL-6 and IgG4 were increased, and the final diagnosis was made as chronic sclerosing dacryoadenitis from the histopathological examinations. Because the level of serum $\mathrm{C}$-reactive protein (CRP) was very low, we selected steroid therapy (30 mg) to treat the dacryoadenitis. However, if the levels of serum IL-6 and CRP were significantly increased, humanized anti-IL-6 receptor antibody (tocilizumab) treatment for a multicentric Castleman disease would have been used because the prognosis becomes poor in such an inflammatory stage of this disease. ${ }^{11}$

In Japan, new criteria for IgG4-positive Mikulicz's disease were published by the Ministry of Health, Labour and Welfare in 2009. According to this report, Castleman disease must be ruled out before a diagnosis of IgG4-positive Mikulicz's disease is made. In our case, we could not rule out Castleman disease as the underlying disease. 


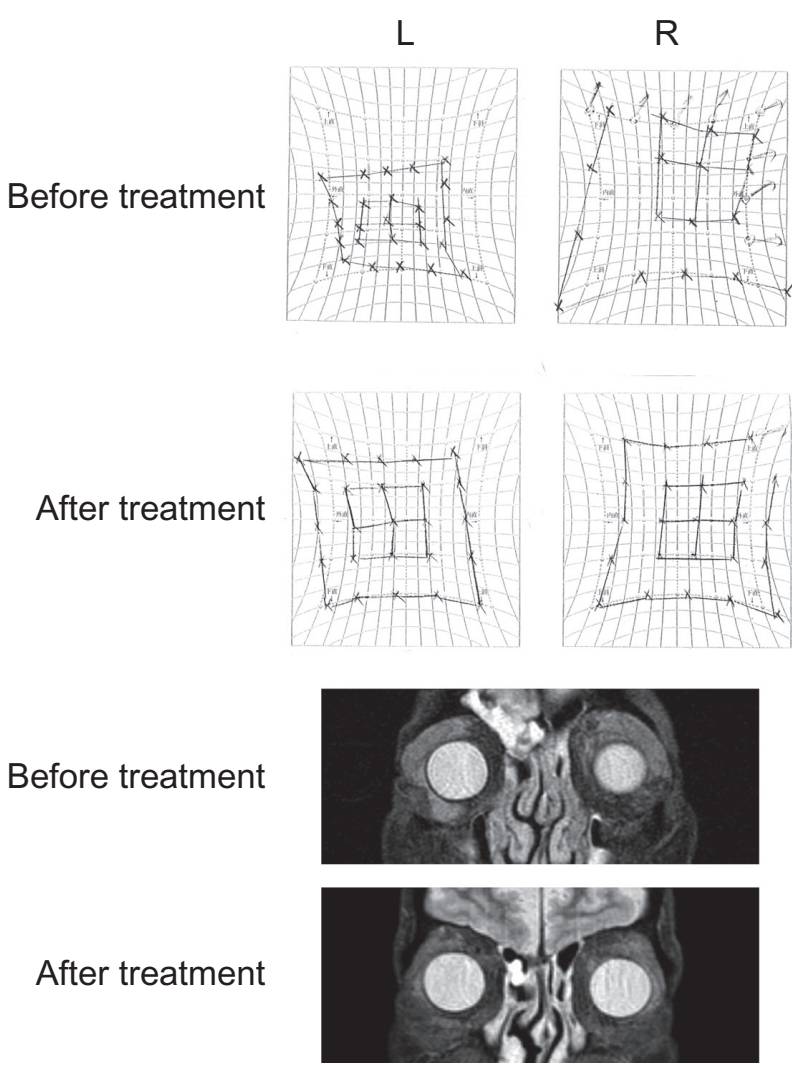

Figure 3 HESS charts and MRI findings before and after oral steroid administration. Both HESS charts and MRI findings were significantly improved after oral steroid administration. Six months after the treatment, no recurrence was observed. The effect of the oral steroid treatment was consistent with the histopathological findings of the specimen from the lacrimal glands.

Thus, the diseases listed in the differential diagnosis of IgG4-positive Mikulicz's disease have similar pathological features and may share in the pathogenesis. In fact, some of the patients with IgG4-related disease and Castleman disease have accompanying malignant lymphomas. ${ }^{6,7}$

In summary, we reported a case of chronic sclerosing dacryoadenitis with high level of the serum IgG4 in a patient who had been diagnosed earlier with Castleman disease from histopathological examinations of specimens biopsied from a swollen submandibular gland. In cases of IgG4-positive Castleman disease, oral steroid or tocilizumab treatment should be selected by referring to the serum IL-6 and CRP levels. The findings in our case suggest that there may be pathological links between IgG4-related diseases and Castleman disease.

\section{Acknowledgments}

This study was supported by the Grant-in-Aid for Scientific Research from Ministry of Education, Science, Sports and Culture in Japan. We thank Professor Duco Hamasaki of the Bascom Palmer Eye Institute, University of Miami for editing the manuscript.

\section{Disclosure}

No conflicts of interest were declared in relation to this paper.

\section{References}

1. Yamamoto M, Harada S, Ohara M, et al. Clinical and pathological differences between Mikulicz's disease and Sjögren's syndrome. Rheumatology (Oxford). 2005;44:227-234.

2. Sato Y, Kojima M, Takata K, et al. Systemic IgG4-related lymphadenopathy: a clinical and pathologic comparison to multicentric Castleman's disease. Modern Pathol. 2009;22:589-599.

3. Ishida F, Kitano K, Kobayashi H, Saito H, Kiyosawa K. Elevated IgG4 levels in a case with multicentric Castleman's disease. Br J Haematol. 1997;99:981-982.

4. Miwa I, Watanabe F, Maruyama Y, et al. A case of Castleman's disease (plasma cell type) in which autoimmune pancreatitis developed 6 years later. Nippon Shokakibyo Gakkai Zasshi. 2007;104:239-244. In Japanese.

5. Miwa I, Maruyama Y, Kageoka M, et al. Retroperitoneal fibrosis and Castleman disease in two patients with high IgG4 levels. Nippon Shokakibyo Gakkai Zasshi. 2008;105:1087-1092. [In Japanese].

6. Sato Y, Ohshima K, Ichimura K, et al. Ocular adnexal IgG4-related disease has uniform clinicopathology. Pathol Int. 2008;58:465-470.

7. Venizelos I, Papathomas TG, Papathanasiou M, Cheva A, Garypidou V, Coupland S. Orbital involvement in Castleman disease. Surv Ophthalmol. 2010;55:247-255.

8. Snead MP, James JN, Snead DR, Robson DK, Rizk SN. Orbital lymphomas and Castleman's disease. Eye (Lond). 1993;7:84-88.

9. Kurokawa T, Suzuki S, Kawaguchi K, Fujisawa N, Yoshimura N. Castleman disease presenting with ophthalmic signs and symptoms. Am J Ophthalmol. 1999;128:114-116.

10. Koppens JM, Pon JA, Allen J, Sloan BH. Castleman's disease of the lacrimal gland. Clin Exp Ophthalmol. 2004;32:108-110.

11. Nishimoto N, Kanakura Y, Aozasa K, et al. Humanized antiinterleukin-6 receptor antibody treatment of multicentric Castleman disease. Blood. 2005;106:2627-2632.
Clinical Ophthalmology

\section{Publish your work in this journal}

Clinical Ophthalmology is an international, peer-reviewed journal covering all subspecialties within ophthalmology. Key topics include: Optometry; Visual science; Pharmacology and drug therapy in eye diseases; Basic Sciences; Primary and Secondary eye care; Patient Safety and Quality of Care Improvements. This journal is indexed on PubMed

Submit your manuscript here: http://www.dovepress.com/clinical-ophthalmology-journal

\section{Dovepress}

Central and CAS, and is the official journal of The Society of Clinical Ophthalmology (SCO). The manuscript management system is completely online and includes a very quick and fair peer-review system, which is all easy to use. Visit http://www.dovepress.com/testimonials. php to read real quotes from published authors. 